Stanford in the case, said the petition presented "a novel idea", and noted that frequently patents have been issued and simultaneously continued with applications for additional claims, and that even though the continued application contains identical "trade-secret" material, it is not subject to disclosure. And he suggested that Wegner \& Bretschneider may have been motivated by "crass commercialiam", since they were at one point planning to publish a book on the Cohen-Boyer patent, a plan that many have been foiled by the file having been closed.

Stephen Budiansky

\section{.. and the new}

NEw YoRK's Columbia University was last week granted a patent that is widely viewed to be of sweeping importance to the future commercial production of proteins from mammalian cell cultures. The process patented was developed by Dr Richard Axel and his colleagues. It enables two new genes to be simultaneously placed and activated in mammalian cells. One acts as a selectable marker, the other produces a protein that is under study or of commercial value.

The ability to introduce selectable markers is a key to the commercial use of mammalian cells in biotechnology applications. The markers allow easy isolation of the transformed cells.

Mammalian cells will probably be used to produce proteins that are toxic to bacteria or unstable in bacterial systems; mammalian cells offer in addition the substantial advantage of being easily induced to secrete their protein products. Thus, unlike bacterial cells, mammalian cells do not need to be destroyed to harvest the product. The ability to maintain stable lines of protein-producing cells also allows for manipulation of environmetal factors to optimize production.

Columbia's Office of Science and Technology is discussing licensing of the patent with several companies. Columbia, which was assigned the patent by the researchers, has said that it will grant nonexclusive licences to "facilitate the transfer" of the technology as rapidly as possible. No details on terms of the licences have been announced as yet.

The research on which the patents are based was published in three principal papers* which have been published over the past six years by Dr Axel, Dr Saul Silverstein of Columbia and Dr Michael Wigler now of Cold Spring Harbor Laboratory.

Foreign patent applications for the process are pending in Western Europe, Japan, Canada and Australia. Two additional US patents covering related work on gene promoters and amplified genes are also pending. Stephen Budiansky

*Wigler, M. et al. Cell 11, 223 (1977)

Wigler, M. et al. Cell 16, 777 (1979)

Wigler, $M$. et al. Proc. natn. Acad. Sci.

U.S.A. 77,3657 (1980).

British birds

\title{
Peregrines prey to nest thieves
}

THE Royal Society for the Protection of Birds (RSPB) claims that a registration system for captive birds of prey which was introduced into Britain last year to prevent theft of eggs from the wild is acting as a "bureaucratic rubber stamp that is condoning crime". The society believes that the system is being widely abused because of ineffective enforcement, and says that the number of eggs of rare species taken illegally this year has been noticeably higher than in previous years.

The scale of the problem is illustrated by the case of the peregrine, a bird that is particularly popular with falconers. RSPB's director, Mr Ian Prestt, says that the society knows of 72 peregrine eyries that have been plundered this year, 10 to 20 per cent of the total British nests. The estimated number of eggs stolen is slightly larger than the number of eggs claimed to have been laid in captivity and so registered under the Wildlife and Countryside Act. Mr Prestt believes that many of the stolen eggs are hatched in incubators and then registered as having been laid by captive birds.

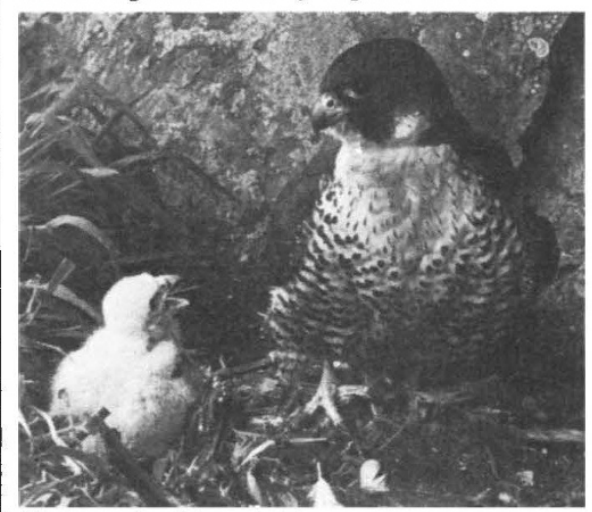

The peregrine falcon at risk

RSPB's director of conservation, $\mathrm{Mr}$ John Parslow, says that the Department of the Environment is unable and unwilling to take enforcement seriously. Part of the problem is that breeders of captive birds are not required to keep detailed records of eggs laid and hatched, so that registering a bird from an illegally obtained egg is quite easy, a fact that is admitted by the Department of the Environment. The society has made suggestions for improvements and offers to help policing but has received no response. But the department says it has yet to be convinced that further measures will be necessary, although it is considering the suggestions and of fers of help from RSPB.

Although some species have to be ringed in the presence of an inspector from the department in order to be legally sold, some of the inspectors are unpaid volunteers who are themselves breeders of captive birds. In other cases registration rings are simply sent through the post. $\mathrm{Mr}$ Parslow says that unless the law can be enforced effectively there is a strong case for a total ban on the keeping of birds of prey.
A major problem facing inspectors is that it is usually impossible to invalidate claims that a particular bird was bred from captive stock, unless an egg is found that has been marked in the wild. But the society is hoping that molecular biology will come to the rescue. The Nuffield Foundation has agreed to sponsor a one-year pilot study, to be carried out by Dr David Parkin at the University of Nottingham, of a possible method of disproving fraudulent claims of parentage. A bank of molecular probes for detecting variants in mitochondrial DNA will be built up in the hope that they will enable checks to be made on maternity through the analysis of blood samples.

Tim Beardsley

\section{Cancer chemotherapy}

\section{New recruits}

\section{Washington}

THE National Cancer Institute (NCI) is spending some $\$ 10$ million this year on a new programme which, it is hoped, will increase the number of cancer patients participating in clinical trials and at the same time keep local physicians in touch with the latest developments in cancer treatment. The money will be distributed this summer to 59 community hospitals or consortia of cancer specialists in 32 states.

The Community Clinical Oncology Program will encourage qualified community physicians to participate in NCI-supported clinical trials at medical centres and in regional clinical cooperative groups that conduct large-scale treatment studies. The programme is expected to provide an additional 5,000 cancer patients a year for clinical research.

One reason for the initiative is that the United States has become the victim of its own success in training physicians to treat cancer patients. Some 80 per cent of cancer patients are believed to receive treatment in their local communities, raising acute problems for clinical researchers who need to carry out large-scale treatment studies.

Dr Robert Frelick, one of the programme directors, cited Hodgkin's disease as an example of the problem. Current chemotherapy has proved so successful that it is being administered throughout the country, leaving a shortage of patients for clinical research centres that aim to reduce the rate of mortality even further.

Each of the 59 community programmes has to undertake to provide at least 50 patients a year who are willing to participate in the research protocols developed by the NCI through affiliated centres. NCI hopes that by upgrading the skills and knowledge of local physicians even those cancer patients who are not participants in clinical trials will receive some benefit from the programme.

Peter David 